\title{
Giving Condolences by Persian EFL Learners: A Contrastive Sociopragmatic Study
}

\author{
Laila Samavarchi (Corresponding author) \\ Yazd University \& Iran Language Institute, Iran \\ E-mail: Laila_samavarchi@yahoo.com \\ Hamid Allami, Assistant Professor \\ Yazd University, Iran \\ E-mail: hallami@yazduni.ac.ir
}

$\begin{array}{lr}\text { Received: May 18, } 2011 & \text { Accepted: October 10, } 2011 \quad \text { Published: February 1, } 2012 \\ \text { doi:10.5539/ijel.v2n1p71 } & \text { URL: http://dx.doi.org/10.5539/ijel.v2n1p71 }\end{array}$

\begin{abstract}
Within Second Language Acquisition (SLA) research area, speech acts studies are often conducted to measure SL learners' pragmatic (in)competence. Unlike other speech acts, the speech act of giving condolences has not yet been the subject of cross-linguistic or cross-cultural studies across Persian and other languages. This initiative study attempts to investigate a comparative analysis of giving condolences across English and Persian. To this end, an English 15-item Discourse Completion Task (DCT) was given to 10 native speakers of English and to 50 Iranian EFL learners who were also given the Persian version of the DCT for the purpose of comparison. The results of a prior pilot study had indicated a significant difference between the two groups. The results of the main study also indicated a difference between the two groups as such some of the Persian EFL learners socioculturally transferred this speech act from their L1 into L2 while some others did not. On the whole, Persian EFL learners were more direct than the English natives while offering their condolences.
\end{abstract}

Keywords: Condolence, Pragmatic competence, Persian EFL learners, Speech act

\section{Introduction}

Knowing a language does not just mean being linguistically competent in that particular language (Hymes, 1972). A linguistically well-formed sentence can be appropriate in one context but completely inappropriate in another situation. When something is said inappropriately in one context or when language is used wrongly, it could lead to misunderstanding or it could even result in hurting someone's feelings. So, to know a language, a learner must be pragmatically competent too rather than just being linguistically competent. Johnston (2008) states that "knowing a language means not just knowing its grammar and vocabulary but also knowing how to structure paragraphs and arguments and participate in conversations the way speakers of the language do, and it means understanding which sentence types can accomplish which purposes in social interaction: what might work as an apology, for example, or how to decline an invitation" (p. 7). This aspect of understanding the purposes behind the sentences is a part of the field of pragmatics which is the study of language use in context and it is said to be the most difficult and challenging aspect of language teaching to be dealt with (Ishihara, 2003). Wolfson (1989) claims that a grammatical or pronunciation error may be easily forgiven by the native speakers of a language, but not a pragmatic. According to Akram (2008), modern linguistics is said to be the study of language as a system of human communication and that 'to speak is to act'. Language can be used to describe reality and to change the existing reality too. Those acts which are used to change the reality are commonly called speech acts which are the functional units in communication. According to Yule (1996), speech acts are speech functions that are realized by way of words. Speech acts include a wide range of functional units such as apologies, compliments, requests, invitations and so on. Yule claims that being able to say the right thing to the right person at the right time would be a great social accomplishment. 
Performing speech acts involves both socio-cultural and sociolinguistic knowledge (Cohen, 1996). Socio-cultural knowledge determines when to perform a speech act and which one is appropriate in a situation in which one is functioning and sociolinguistic knowledge determines the actual linguistic realization of each speech act.

A large number of second language acquisition (SLA) studies have focused on speech acts, with regard to both pragmalinguistics and sociopragmatics. The sociopragmatic context shouldn't be ignored and because of that, recognizing cultural contexts of speech is gaining importance, in order to pre-empt cross-cultural pragmatic failure (Fahey, 2005). Pragmatic failure i.e. inability to respond appropriately in a particular context can be due to interlingual transfer or just due to non-exposure to the norms (Kasper, 1992). Interlingual transfer of pragmatics is the result of the knowledge of their first language that learners bring with them.

While most of the sociopragmatic studies have focused on different face-saving or face-threatening acts such as complimenting, complaining, apologizing, refusing and so forth, such a focus has not been given to the speech act of condoling. Hence, this paper aims to find out whether or not Iranian speakers of English commit sociocultural transfer while giving condolences to somebody.

\section{Previous Studies}

A number of cross-linguistic studies have investigated how the Persian learners of English realize different speech acts in English. A study was conducted to compare and contrast the use of politeness strategies within the speech acts of favor asking, griping and complaint across the Persian and British English communities (Yarmohammadi, 2003). The monolingual speakers of Persian (MSP) and the Persian learners of English (EFL) were said to use more than twice as many as strategies in comparison to the American native speakers of English (NSE). Also, the NSP and EFL groups were more indirect than the NSE group which was said to be the result of transfer from Persian to English for the EFL.

As far as the speech act of requestives is concerned, a cross-cultural study was conducted to compare the patterns in the requests of native Persian speakers and native American speakers (Eslamirasekh, 1993). Results showed that Persian speakers were much more direct than American speakers when making requests and it was suggested that Persian speakers may compensate for the directness by using strategies like alerters, supportive moves and internal modifiers. Another cross-sectional investigation into the speech act of requesting by Iranian EFL learners and Australian native speakers of English was conducted by Jalilifar (2009). The results indicated that the Iranian EFL learners were developing pragmatically with a movement from direct to indirect strategies. The higher proficiency learners overused the indirect strategy of requesting while the lower proficiency ones overused the most direct strategy. On the other hand, the Australian native speakers made a balanced use of both the indirect and direct strategies. With regards to the influence of a social variable (social distance), it was concluded that the Iranian EFL learners didn't acquire the sufficient sociopragmatic competence.

Another study in the Iranian context was conducted on 'supportive moves' used in making Requestive Speech Act (RSA) by Persian speakers (Nodoushan \& Allami, 2011). The Discourse Completion Test for the study was designed by taking into consideration six scenarios differing in the degree of formality and Perceived Situation Seriousness. The results suggested that in order to negotiate face in RSA, Persian speakers employ internal and external discourse moves, the choice of which was determined by the important factor of Perceived Situational Seriousness.

Also, the speech act of apologizing has been studied to see if apologies are as formulaic in Persian as they are in English (Afghari, 2007). The results of the research indicated that Persian apologies are formulaic in pragmatic structure. It was also found that the two context-external variables of social distance and social dominance had a significant effect on the frequency of intensifiers used in varying situations.

With regards to the speech act of expressing gratitude, Farnia and Suleiman (2009) found that Iranian EFL learners and American native speakers use the same type of strategies but what differed was the frequency of use of the strategies. Native speakers resorted to fewer strategies while expressing gratitude in comparison to the Iranians. The reason for this difference was said to be the type of society in which the Iranians and Americans live. The Iranian society is said to be traditionally non-egalitarian society, unlike the American society, where speakers choose strategies depending on the hierarchical differences between the speaker and hearer.

Allami and Naeimi (2011) investigated realization of the speech act of refusal by Persian EFL learners. It was found that there were differences between Persian learners and American speakers when it came to the use of semantic formulas with regards to frequency, shift and content. The results indicated that the Persian learners pragmatically transferred from their native language and that L2 proficiency correlated positively with pragmatic transfer i.e. low-proficiency learners tended to transfer less L1 sociocultural norms to L2. 
Coming to the previous research concerning the speech act of giving condolences, only a few studies have focused on mourning and death but not directly on the way people in everyday lives offer their condolences. Moore (2002) has studied obituaries in newspapers as a text type. Holt (1993) has studied death announcements in everyday conversations while Roniger (1994) has focused on death announcements in the Hebrew press.

As far as the act of giving condolences is concerned, Fenton-Smith (2007) has attempted to study the offering of the diplomatic condolences sent by several nations on the death of the Palestinian president, Yasser Arafat. In this paper, the diplomatic condolence message was treated as a recognizable text type used by the government to construct ideological positions. Fenton- Smith (2007) comes to the conclusion that 'language plays a subtle but yet critical role in global restructuring.'

But so far no paper can be cited that directly reflects on the act of giving condolences in everyday conversation.

\section{Objectives and Significance of the Study}

This study intends to investigate the pragmatic competence of Iranian learners of English. The focus will be one particular speech act i.e. expressive. Expressives as mentioned before are those speech acts which are performed for expressing some kind of feeling. It could be thanking, apologizing, complimenting, condoling, etc. This paper focuses on one expressive which is giving condolences on somebody's death. The reason for focusing on this one particular speech act is threefold: firstly because losing somebody close to you is a very severe situation and inability to act and respond appropriately could show indifference or even insensitivity. Secondly because speech acts such as thanking, apologizing, and complimenting have been studied a lot on whereas giving condolences or condoling has not been paid attention to in research studies and even in textbooks or courses dealt with in classes. No study until now has focused on such a speech act and this study intends to be the first one.

For the purpose of the study, the following research questions have been proposed:

1) Can Persian EFL learners of English offer their condolences appropriately in a pragmatically competent manner?

2) Do Persian EFL learners of English transfer their knowledge of first language to the second language while offering condolences?

3) Do Persian EFL learners of English offer condolences in English based on their own interlanguage?

Since none of the studies have focused on the speech act of giving condolences except for diplomatic condolences, especially in Iran, this study has some significance as the results could show the pragmatic incompetence of learners which questions the current textbooks and courses being offered.

\section{Method}

\subsection{Participants}

The discourse completion test was given to 50 (10 male, 35 female) Persian EFL learners in language institutes and Yazd University. All participants were given the Oxford Quick Placement Test (2001) to be able to determine their level of proficiency. To be able to compare the learners' pragmatic development to that of native English speakers, the same test was given to 10 English native speakers.

$<$ Insert Table 1 here $>$

\subsection{Materials}

A discourse completion test was used in this study as shown in appendix 1 and the Persian version of the test was also used for the purpose of comparison between the responses by the Persian EFL learners in both languages. The test consisted of 15 items which had been designed by taking into consideration the three factors: context (formality/informality), social distance and power. The number of items in the pilot study was 5 which were increased to 15 for the purpose of the main study. This test was designed to check the learners' pragmatic ability with respect to how they give their condolences to particular people in different contexts.

\subsection{Pilot Study}

For the purpose of checking the feasibility of the main study, a pilot study was conducted. The DCT used in the pilot test comprised of 5 items. The discourse completion test was given to 5 Persian EFL learners of English and 5 English native speakers. They were also given the same test in Persian for the purpose of comparison to see if they transfer their L1 knowledge in giving condolences. After comparison of their responses in the discourse completion test in English and Persian, it was found that some learners tend to transfer from the first 
language while some don't. For example, one of the learners' response was 'Peace be upon her.' which has been transferred from Persian.

To see if Persian EFL learners of English have achieved native-like pragmatic competence, the test was e-mailed to 5 American English speakers. After comparison of the tests completed by non-native English speakers and native English speakers, it was found that Persian EFL learners of English were nowhere near the native speakers' pragmatic competence. For example, one of the non-native speaker's response was 'I'm so sorry about your grandmother but you know all of us are mortal.' And another non-native English teacher's response was 'It's life. Today is her turn, tomorrow mine, and after that yours.' These responses were also sent to the 5 native English speakers to comment on their appropriateness. Apparently, these responses were quite insensitive. This leads to the initial hypothesis that the Persian EFL learners in Iran who have not been exposed to an English-speaking environment are not pragmatically competent as far as giving condolences is concerned. To be able to generalize the results, this pilot study was followed by the main study in which the number if items in the DCT and the number of participants was increased.

\section{Data Collection and Data Analysis}

The DCT was given to the participants and they were given. Then the following session, they were given the test in Persian. The English native speakers were sent the test as an e-mail attachment on Microsoft Word 2003 and were asked to respond and send it back.

For the pilot study, data were analyzed quite subjectively. But for the main study, data was analyzed via a coding system in terms of strategies used to give condolences. This analysis was based on content of the responses as discussed in Section 6. This could show whether Persian EFL learners tend to be similar to their English counterparts or whether they translate and hence, negatively transfer from their L1 or not.

Also, functional analysis (Ellis \& Barkhuizen, 2005) was carried out. The following steps were carried out as far as data collection and analysis is concerned.

1) Identification of the specific function to be investigated i.e. the illocutionary act of giving condolences.

2) Collecting samples of learner language using a discourse completion task.

3) Identification of the different linguistic forms i.e. the linguistic strategies used to perform the function of condoling. ( Detailed taxonomies of linguistic forms used by both L2 learners and native speakers are available for speech acts of requesting and apologizing but unfortunately no such taxonomy is available for the speech act of giving condolences.)

4) Counting the frequency of use of each form used to realize this particular function. This analysis has been used to show the dominant form used to realize the function by native and non-native speakers.

\section{Results and Discussion}

After the collection of the data, they were coded. The coding, as mentioned previously, was based on the content of the responses which had been categorized into the following headings.

1) Direct condolence (I give you my condolences.)

2) Apologetic

2.1) Apologetic + offer to help ( I'm so sorry. If you need help, I'll be there.)

2.2) Apologetic + philosophical utterance (I'm sorry; I hope it'll be the last tragedy on your life.)

2.3) Apologetic + appreciation of the dead (I'm sorry; she was so nice.)

2.4) Apologetic + religious (I'm sorry, May God bless him!)

2.5) Apologetic

3) Religious (God bless him! / God will give him a place in paradise.)

4) Offering help (If you need any help, let me know .You can count on me anytime.)

5) Consoling (comforting/sympathizing) (Be calm and don't worry.)

6) Enquiring (What happened? / How did it happen?)

7) Silence

The percentage of the use of the particular strategies by the Persian EFL learners and English natives have been calculated and presented in the table below. 


\section{$<$ Insert Table 2 here $>$}

The table above shows the differences between the Persian EFL learners and English natives when it comes to giving condolences. Differences exist between the participants especially when it comes to being direct or indirect. The great majority of Persian speakers offered the condolences directly by using the formulaic structure "تسليت مى كويم" while much fewer number of Persian EFL learners and English natives tended to use this direct strategy. English natives tended to use the phrase "I'm sorry for your loss" much more frequently than the other more direct strategies like "I offer/give you my condolences". Also, the English natives tended to be indirect by just being sympathetic and consoling the bereaved.

Another important point that can be noted is that some of the Persian EFL learners tended to directly translate from their L1 into their L2. For example, the formulaic expression used by Persian speakers " تسليت مى كويم " was literally translated by them into English and hence, some of their responses like " I condole with you." seemed to reflect the influence of the L1 on L2. Also, another expression used commonly by Persian speakers was " غم آخرتان باند. EFL learners used expression such as "I'm sorry." which was almost similar to the expressions used by English natives. This indicates the difference among Persian EFL learners which in turn points to the fact that there is some interlanguage pragmatics which is in play.

On the whole, it can be said that Persian speakers tend to be more direct in Persian than in English when it comes to giving their condolences which in turn is more direct than English natives. Hence, English natives may be said to be indirect when condoling i.e. indirect when compared to Persian EFL learners both in English and Persian.

\section{Conclusion}

In this study, an attempt is made to study the speech act of giving condolences from the sociopragmatic perspective. The aim of the study was to find out whether Persian EFL learners resort to sociocultural transfer while performing this particular speech act or whether they perform like English natives or whether they tend to make use of their interlanguage pragmatics.

With regards to the first research question as to whether Persian EFL learners of English offer their condolences appropriately in a pragmatically competent manner, some of the learners almost performed like their English counterparts.

Regarding the second research questions, it can be said some of these learners performed this speech act like they do in Persian. In other words, these learners tend to transfer the act of condoling socio-culturally from their L1 to L2.

But when it comes to the final research question of whether these learners offer condolences in English based on their own inter-language, it was found that some of them performed differently from both themselves in their L1 and from English natives indicating the existence and use of their interlanguage pragmatics. This finding points to the cultural differences that exist between these two groups of speakers; one from the East and the other from the West. Summing up the results, it can be said that the Persian speakers and EFL learners are more direct than the English natives while condoling someone on the death of their beloved or their acquaintances.

From a pedagogical point of view, this can be an indicator of the fact that even though these learners have not yet attained the pragmatic competence in L2 but they are progressing towards this competence and hence, it can be said that attainment of native-like pragmatic competence is actually possible if provided exposure to and made it noticeable to the learners.

These findings indicate that there is a need for explicit teaching of speech acts in educational settings. Expecting all learners to attain native-like pragmatic competence may be a bit far-fetched but more attempt needs to be made for making the learners aware of the sociopragmatic aspect of the language they are learning. Teachers need to understand the importance of the cross-cultural differences that exist and use specific strategies that can be employed in the classrooms. Research has shown that if appropriate strategies are employed, learners can successfully acquire the speech acts without resorting to sociocultural transfer. Eslami-Rasekh, Eslami-Rasekh and Fatahi (2004) attempted to investigate the effect of explicit metapragmatic instruction on the comprehension of speech acts of requesting, apologizing and complaining. This was done by using different activities in the classroom such as teacher-fronted discussions, cooperative grouping, role plays and other pragmatically oriented tasks. The results indicated that such classroom activities help improve the learners' speech act comprehension and that explicit instruction can help develop pragmatic competence. Focusing on one particular speech act, Eslami-Rasekh and Mardani (2010) investigated the effects of explicit teaching of apology speech act. Ghobadi and Fahim (2009) investigated the effect of explicit teaching of English "thanking formulas" on Iranian EFL 
intermediate level students. The results indicated that "instruction had an impressively positive effect on raising students' sociopragmatic awareness as well as their hindrance of L1 pragmalinguistic transfer to L2 (second language)" and that learners "will not be able to understand the differences between the two languages without being exposed to instructions."

These studies provide empirical evidence to the fact that explicit teaching of speech acts is useful and can create greater awareness among the learners. Hence, more attempts have to be made to incorporate explicit teaching of speech acts in classroom procedures.

\section{References}

Afghari, A. (2007). A sociopragmatic study of apology speech act realization patterns in Persian. Speech Communication, 49(3), 177-185. http://dx.doi.org/10.1016/j.specom.2007.01.003

Akram, M. (2008). Speech Acts: A Contrastive Study of Speech Acts in Urdu and English. Asian EFL Journal, 10(4).

Allami, H. \& Naeimi, A. (2011). A Cross-Linguistic Study of Refusals: An Analysis of Pragmatic Competence Development in Iranian EFL Learners. Journal of Pragmatics, 43(1), 385-406. http://dx.doi.org/10.1016/j.pragma.2010.07.010

Brown, H.D. (2007). Principles of Language Learning and Teaching. ( $5^{\text {th }}$ ed.) White Plains, NY: Pearson Education.

Brown, P. \& Levinson, S. (1987). Politeness: Some Universals in Language. Cambridge: Cambridge University Press.

Cohen, A. (1996). Developing the ability to perform speech acts. Studies in Second Language Acquisition, 18, 253-267. http://dx.doi.org/10.1017/S027226310001490X

Ellis, R. \& Barkhuizen, G. (2005). Analysing Learner Language. Oxford: Oxford University Press.

Eslamirasekh, Z. (1993). A cross-cultural comparison of the requestives speech act realization patterns in Persian and American English. In L. Bouton \& Y. Kachru (Eds.), Pragmatics and language learning, 4 (pp. 85-103). Urbana-Champaign, IL: Division of English as an International Language.

Eslami-Rasekh, A. \& Mardani, M. (2010). Investigating the Effects of Teaching Apology Speech Act, with a Focus on Intensifying strategies, on Pragmatic Development of EFL Learners: The Iranian Context. The International Journal of Language Society and Culture, 30, 96-103.

Eslami-Rasekh, Z, Eslami-Rasekh, A. \& Fatahi, A. (2004). The Effect of Explicit Metapragmatic Instruction on the Speech Act Awareness of Advanced EFL Students. Teaching English as a Foreign or Second Language, $8(2), 1-12$.

Fahey, M.P. (2005). Speech acts as intercultural danger zones: A cross-cultural comparison of the speech act of apologising in Irish and Chilean soap operas. Intercultural Communication, 8.

Farnia, M. \& Suleiman, R.R.R. (2009). An Interlanguage Pragmatic Study of Expressions of Gratitude by Iranian EFL Learners - A Pilot Study. Malaysian Journal of ELT Research, 5, 108-140. [Online] Available: www.melta.org.my

Fenton-Smith. B. (2007). Diplomatic condolences: Ideological positioning in the death of Yasser Arafat. Discourse \& Society, 18(6), 697-718. http://dx.doi.org/10.1177/0957926507082192

Ghobadi, A. \& Fahim, M. (2009). The effect of explicit teaching of English "thanking formulas" on Iranian EFL intermediate level students at English language institutes. System, 37(3), 526-537. http://dx.doi.org/10.1016/j.system.2009.02.010

Golembeski, D. \& Yuan, Y. (1995). Responding to compliments: A Cross-linguistic study of the English pragmatics of Chinese, French and English speakers: Paper presented at the International Conference on Pragmatics and Language Learning, University of Illinois at Urbana-Champaign, Illinois.

Holt, E. (1993). The Structure of Death Announcements: Looking on the Bright Side of Death, Text 13(2): 189-212. http://dx.doi.org/10.1515/text.1.1993.13.2.189

Hymes, D. (1972). On communicative competence. In J. B. Pride \& J. Holmes (Eds.), Sociolinguistics: Selected readings. Baltimore: Penguin.

Ishihara, N. (2003). Giving and responding to compliments. In K. Bardovi-Harlig \& R. Mahan Taylor (Eds.), Teaching pragmatics. Washington DC: Office of English Programs, U.S. Department of State. 
Jalilifar, A. (2009). Request Strategies: Cross-Sectional Study of Iranian EFL Learners and Australian Native Speakers. English Language Teaching, 2(1), 46-61.

Jeon, Y. (1996). A Descriptive study on the development of pragmatic competence by Korean learners of English in the speech act of complimenting. Unpublished doctoral dissertation. Texas A\&M University.

Johnston, B. (2008). Discourse analysis. Carlton: Blackwell Publishing.

Kasper, G. (1992). Pragmatic Transfer. Second Language Research, 8(3), 203-231. http://dx.doi.org/10.1177/026765839200800303

Moore, S.H. (2002). Disinterring Ideology from a Corpus of Obituaries: A Critical Post Mortem. Discourse \& Society, 13(4): 495-536. http://dx.doi.org/10.1177/0957926502013004071

Roniger, L. (1994). A Long-Run View of Israeli Society through the Looking Glass of Mourning Announcements in the Press. Omega, 29(3): 205-17. http://dx.doi.org/10.2190/2N31-CL0Y-GQ2K-3MCE

Salmani-Nodoushan, M. \& Allami, H. (2011). Supportive discourse moves in Persian requests. International Journal of Language Studies, 5(2), 205-234.

Wolfson, N. (1981). Invitations, compliments, and the competence of the native speakers. International Journal of Psycholinguistics, 8, 7-22.

Yarmohammadi, N. (2003). Politeness Strategies in English and Persian in Contrast. Unpublished doctoral dissertation. Allame Tabataba'ee University, Tehran.

Yule, G. (1996). Pragmatics. Oxford: Oxford University Press.

\section{Appendix 1}

\section{Please read the following and respond as you think appropriate.}

1) You hear that your school teacher's mother has passed away and you see your teacher the next day in your school corridor. What would you tell him/her?

2) After hearing about the death of your friend's grandmother, you go to his/her house to see $\mathrm{him} / \mathrm{her}$. What would you tell him/her?

3) You come to know that your classmate's uncle whom he loved dearly has expired. You see your classmate in class and go to talk to him/her. What would you tell him/her?

4) Your neighbor's father has passed away and on hearing that, you go to their house to condole them. What would you say?

5) Your subordinate's father has passed away and you go to the funeral service. On seeing your subordinate there, what would you say?

6) When you go to work in the morning, you come to know that your old colleague's brother has passed away. You go to his/her house later to see him/her. What you would tell him/her on seeing him/her?

7) On arriving at the office, someone tells you about your new colleague's brother's death. You call your colleague to talk to him. What would you say?

8) You are at work in your new boss's office discussing something important and someone calls your boss and tells him/her that his/her grandmother has expired. What would you say if you were in that situation?

9) On the weekend, you come to know that you boss's wife has died whom you have known for quite a while. You go to the funeral service and on seeing your boss, what would you tell him/her?

10) Your secretary who has worked for you quite some time doesn't come to work. On calling her, you find out that her mother is no more. What would you tell her?

11) Your new secretary comes to your office to ask for a leave as she needs to go somewhere immediately. On asking the reason, she tells you that her second cousin has died. What would you tell her?

12) At work you are informed that the janitor's wife has died. You go to his house to condole him. What would you say when you see him?

13) You are informed that your brother's wife has died. You rush to see your brother. On seeing him, you say.... 
14) When you return home, you come to know that your wife's best friend has died in an accident. What do you tell your wife?

15) You come to know your son's favorite teacher has died. When you see your son, what do you tell him?

Table 1. Descriptive Information on Iranian Participants

\begin{tabular}{|c|c|c|}
\hline Gender & Male & Female \\
\hline Number of participants & 10 & 35 \\
\hline Average age & 30 & 28 \\
\hline Level & Advanced & Advanced \\
\hline
\end{tabular}

Table 2. Percentage of the Strategies Used by the Participants

\begin{tabular}{|c|c|c|c|}
\hline \multirow[t]{2}{*}{ Code } & \multicolumn{2}{|c|}{ English } & \multirow{2}{*}{$\begin{array}{c}\text { Persian } \\
\text { Persian speakers }\end{array}$} \\
\hline & Persian EFL learners & English natives & \\
\hline 1 & 10 & 5 & 70 \\
\hline 2.1 & 3 & 5 & 0 \\
\hline 2.2 & 6 & 0 & 10 \\
\hline 2.3 & 5 & 0 & 0 \\
\hline 2.4 & 10 & 8 & 0 \\
\hline 2.5 & 20 & 45 & 0 \\
\hline 3 & 18 & 5 & 15 \\
\hline 4 & 11 & 0 & 5 \\
\hline 5 & 12 & 23 & 0 \\
\hline 6 & 0 & 6 & 0 \\
\hline 7 & 5 & 3 & 0 \\
\hline
\end{tabular}

